\title{
PENGARUH PENGGUNAAN MEDIA SOSIAL WHATSAPP DAN BOOKLET TERHADAP PENGETAHUAN DAN SIKAP SISWA TENTANG ROKOK DI SMA NEGERI 13 MEDAN
}

\author{
Aldo Al Gafi ${ }^{1}$, Wisnu Hidayat ${ }^{2}$, Frida Lina Tarigan ${ }^{3}$ \\ ${ }^{1}$ Progam Studi Magister Ilmu Kesehatan Masyarkat, Direktorat Pasca Sarjana, Universitas Sari Mutiara Indonesia Medan \\ Email: aldoalgafi8@gmail.com \\ ${ }^{2}$ Direktorat Pasca Sarjana Ilmu Kesehatan Masyarakat, Universitas Sari Mutiara Indonesia Medan \\ Email:hrwisnu@yahoo.com \\ ${ }^{3}$ Direktorat Pasca Sarjana Ilmu Kesehatan Masyarakat, Universitas Sari Mutiara Indonesia Medan \\ Email: frida_tarigan@yahoo.co.id
}

\begin{abstract}
ABSTRAK
Merokok merupakan salah satu masalah kesehatan masyarakat di Indonesia dengan mengingat bahwa merokok merupakan salah satu faktor risiko utama dari beberapa penyakit kronis yang dapat mengakibatkan kematian.Merokok dikalangan remaja disebabkan oleh rasa ingin tahu atau mencoba-coba pengalaman baru, mencoba menghilangkan kejenuhan, ingin dianggap lebih jantan dan ingin diterima dikelompoknya. Tujuan dari penelitian ini adalah untuk menganalisis pengaruh penggunaan media sosial whatsapp dan booklet terhadap pengetahuan tentang rokok dan sikap siswa di SMA Negeri 13 Medan. Penelitian ini merupakan penelitian eksperimen semu. Populasi penelitian adalah seluruh siswa SMAN 13 Medan kelas 11 tahun ajaran 2018/2019 sebanyak 128 orang laki-laki dan sampel diperoleh sebanyak 21 siswa laki-laki untuk kelompok media sosial WA) dan 21 siswa laki-laki untuk kelompok booklet. Metode analisa data yang digunakan dalam penelitian ini terdiri dari analisa univariat dan bivariat. Hasil penelitian diperoleh sebagai berikut: 1) Penggunaan media sosial whatsapp berpengaruh terhadap pengetahuan tentang rokok dan sikap siswa, 2) Penggunaan media booklet berpengaruh terhadap pengetahuan tentang rokok dan sikap siswa. Dari hasil penelitian yang diperoleh disampaikan saran yaitu siswa dapat menambah pengetahuannya melalui beberapa cara diantaranya dengan mencari informasi melalui media internet atau buku yang berkaitan dengan rokok dan merokok serta bahaya yang ditimbulkan akibat merokok sehingga dapat memahaminya dan merubah sikap kearah yang lebih dan menghasilkan perilaku yang baik pula.
\end{abstract}

Kata Kunci: Pengetahuan; Sikap, Rokok; Media Sosial Whatsapp; Booklet

\begin{abstract}
Smoking is one of the public health problems in Indonesia by remembering that smoking is one of the main risk factors of several chronic diseases that can lead to death. Smoking among adolescents is caused by curiosity or trying out new experiences, trying to eliminate boredom, wanting to be considered more male and want to be accepted in the group. The purpose of this study was to analyze the effect of the use of whatsapp social media and booklets on knowledge about cigarettes and student attitudes at SMA Negeri 13 Medan. This research is a quasi experimental study. The study population was all students of SMAN 13 Medan class 11 in 2018/2019 with 128 male students and the sample was 21 male students for the social media group WA) and 21 male students for the booklet group. Data analysis methods used in this study consisted of univariate and bivariate analyzes. The results were obtained as follows: 1) The use of whatsapp social media affected the knowledge of cigarettes and student attitudes, 2) The use of booklet media influenced the knowledge of cigarettes and student attitudes. From the research results obtained, suggestions are given that students can increase their knowledge through a number of ways including finding information through internet media or books relating to smoking and smoking as well as the dangers posed by smoking so that they can understand it and change attitudes towards more and produce good behavior. also.
\end{abstract}

Keywords: Knowledge; Attitude, Cigarettes; Whatsapp Social Media; Booklet 


\section{PENDAHULUAN}

Merokok merupakan salah satu masalah kesehatan masyarakat di Indonesia dengan mengingat bahwa merokok merupakan salah satu faktor risiko utama dari beberapa penyakit kronis yang dapat mengakibatkan kematian (Sirait, 2002).

Menurut The Tobacco Atlas 3rd, terkait persentase penduduk dunia yang mengkonsumsi tembakau didapatkan sebanyak 57\% pendudukan Asia dan Australia, 14\% pada penduduk Eropa Timur dan pecahan Uni Soviet, 12\% penduduk Amerika, 9\% penduduk Eropa Barat dan 8\% pada penduduk Timur Tengah serta Afrika. Sementara itu ASEAN merupakan sebuah kawasan dengan $10 \%$ dari seluruh perokok dunia dan $20 \%$ penyebab kematian global akibat tembakau. Persentase perokok pada penduduk di negara ASEAN tersebar di Indonesia (46,16\%), Filipina $(16,62 \%)$, Vietnam $(14,11 \%)$, Mymar $(8,73 \%)$, Thailand $(7,74 \%)$, Malaysia $(2,9 \%$, Kamboja $(2,07 \%)$, Laos $(1,23 \%)$, Singapura (0,39\%) dan Brunei (0,04\%) (Kemenkes RI, 2016).

Lebih dari 3000 jurnal dan penelitian yang dipublikasikan sejak tahun 1970-an menunjukkan bahaya merokok terhadap kesehatan manusia namun ironisnya sejak tahun 1998 hingga sekarang, Indonesia menempati urutan kelima negara pengkonsumsi rokok terbanyak dan urutan ketiganegara dengan jumlah perokok terbanyak di dunia. World Health Organization (WHO) memprediksi bahwa tahun 2020, penyakit yang disebabkan oleh rokok akan mengakibatkan kematian sekitar 8,4 juta jiwa di seluruh dunia dan setengahnya berasal dari wilayah Asia. Prevalensi perokok pada laki-laki 46,8 \% dan perempuan 3,1\% dengan usia 10 tahun ke atas yang diklasifikasikan sebagai perokok. Jumlah perokok di Indonesia telah mencapai 62,8 juta, dan $40 \%$ berasal dari kalangan ekonomi bawah (WHO, 2016).

Tingkat konsumsi rokok di Indonesia terus mengalami peningkatan dari tahun ke tahun. Selama kurun waktu antara tahun 1970 hingga 2013, konsumsi rokok di Indonesia meningkat tujuh kali lipat dari 33 milyar batang menjadi 217 milyar batang. Pada tahun 2014 menjadi 240 milyar batang rokok pertahun. Dengan jumlah perokok di Indonesia lebih dari 60 juta dan konsumsi rokok yang mencapai 240 milyar batang pertahun, maka dapat dikalkulasi konsumsi rokok ratarata per hari yaitu 10,95 batang (WHO, 2016).

Riset Kesehatan Dasar pada tahun 2013 diketahui bahwa penduduk Indonesia berusia $>15$ tahun yang merokok sebesar $28,2 \%$, kadang-kadang merokok sebesar $6,5 \%$, dan mantan perokok sebesar 5,4\%. Jumlah perokok laki-laki sebesar 65,9\% dan perempuan sebesar 4,2\%. Jumlah konsumsi rokok pada usia $\geq 10$ tahun rata-ratanya adalah 12,3 batang rokok atau 1 bungkus rokok. Di Indonesia prevalensi perokok yang paling banyak berada di Bangka Belitung dengan jumlah konsumsi rokok 18 batang perhari. Jumlah perokok aktif laki-laki pada umur 30-34 tahun sebesar 33,4\% (Riskesdas, 2013).

Riskesdas pada tahun 2017 menunjukkan jumlah perokok di Indonesia mencapai 29,3\% dan dari data perokok di Indonesia, sebanyak 40 persen adalah orang miskin. Dua dari tiga pria di Indonesia merupakan seorang perokok dan sebanyak 60\% mulai merokok dari usia 9 sampai 16 tahun. Selain itu, jika digabungkan, perokok wanita di dunia, memiliki presentase yang besar. Akan tetapi, di Indonesia angka perokok wanita tidak besar namun semakin tahun naik 0,7 hingga 2,9 persen dan sebanyak 60 persen penghasilan digunakan untuk membeli rokok. Hal ini dikarenakan di Indonesia memiliki harga rokok termurah. Sementara itu sejak tahun 2013 prevalensi merokok pada remaja (10-18 tahun) terus meningkat, yaitu 7,2\% (Riskesdas 2013), 8,8\% (Sirkesnas 2016) dan 9,1\% (Riskesdas 2018). 
Efektifitas promosi kesehatan melalui media online telah terbukti efektif. Hasil penelitian menunjukkan adanya pengaruh pemberian promosi kesehatan melalui media sosial terhadap pengetahuan tentang bahaya merokok pada mahasiswa PSIK semester 8 di Universitas Muhammadiyah Yogyakarta dengan tingkat pengetahuan lebih tinggi (Ghazali, 2014).Salahsatu media online yang paling sering digunakan adalah penggunaan whatsapp(WA).mPenggunaan whatsapp di dunia meningkat tajam, pada September 2015, WAmengumumkan sudah mempunyai 900 juta pengguna aktif. WhatsApp merupakan teknologi InstantMessenger seperti SMS menggunakan data dari internet dengan fitur pendukung yang lebih menarik dan mudah untuk digunakan. Pembelajaran di era digital sekarang ini sangat terbantu dengan kehadiran aplikasi whatsapp(Jumiatmoko,2016).

Di Indonesia sendiri, hampir $40 \%$ penduduknya menggunakan WA sebagai sarana komunikasi. Whatsapp menjadi aplikasi yang paling banyak didownload oleh semua kalangan di Indonesia. Sebut saja anak-anak, remaja, hingga orangtua memilih aplikasi ini sebagai media untuk berkomunikasi dengan teman-teman, keluarga, hingga rekan kerja.Dengan pengguna yang begitu banyak yaitu sekitar 1,5 Miliar di dunia,tentunya memiliki banyak keunggulan. Keunggulankeunggulan inilah yang membuat orang Indonesia menggunakan WA(Sabiq, 2019). Keunggulan dari WA tersebut diantaranya adalah WA dapat mengirimkan tulisan, gambar, video, audio dan pesanan suara dengan mudah.

Selain promosi kesehatan atau memberikan pendidikan kesehatan melalui media WA,booklet juga seringdigunakan sebagai alat sarana promosi kesehatan. Media booklet menampilkan gambar-gambar yang menarik, lebih lengkap, lebih praktisuntuk dibawa dan mudah dipelajari dimana saja dibandingkan leaflet dan mediaini juga tidak memerlukan arus listrik yang kadang menjadi kendala pendidikankesehatan dengan media slide (Notoatmodjo, 2012).

Media booklet memiliki beberapa kelebihan yangdiantaranya adalah dapat menimbulkan tanggungjawabsecara mandiri dari setiap responden terhadappengetahuan atas dasar informasi yang diterimamelalui media karena booklet. Booklet diberikankepada masing-masing individu sehingga dapatdipelajari setiap saat (Aini, 2010). Kelebihan lainnya adalah bookletdapat dipelajari setiap saat karena didesain dalam bentuk buku serta memuat informasi lebih banyak (Roza, 2012).

Berdasarkan studi pendahuluan yang dilakukan peneliti di SMA Negeri 13 Medan diketahui melalui wawancara kepada guru BP bahwa mayoritas siswa mereka memiliki handphone dengan berbagai fitur seperti media sosial FB, WA dan pada umumnya digunakan untuk berkomunikasi dan mencari informasi.Diantara beberapa siswa, mereka pernah menangkap basah 6 siswa kelas 11 yang sedang merokok di sekitar luaran lingkungan sekolah pada tahun ajaran 2017/2018 sementara untuk tahun ajaran 2018/2019 telah ditemukan 2 orang siswa yang kedapatan merokok. Siswa tersebut diberikan sanksi dengan memanggil orangtuanya ke sekolah untuk diberi pemahaman tentang peraturan sekolah yang diantaranya adalah siswa dilarang merokok. Menurut informasi yang diperoleh dari guru BP bahwa anak-anak yang merokok tersebut disebabkan pergaulan mereka dengan orang yang merokok karena khawatir tidak diterima dilingkungannya jika tidak merokok. Bagi mereka bahwa dengan merokok merupakan suatu identitas diri. Selain itu ada yang merokok karena mengatasi stres yang sedang mereka alami. Dengan melihat hal tersebut dapat disimpulkan sementara bahwa terdapat beberapa siswa memiliki pengetahuan yang rendah tentang rokok dan sikap yang kurang responden tentang 
bahaya rokok. Untuk mengatasi hal tersebut, peneliti mencoba untuk melakukan eksperimen melalui media WA dan booklet agar siswa dapat memahami tentang rokok dan dampaknya.

Dari beberapa uraian di atas serta dengan mengacu kepada fenomena di tempat penelitian, peneliti mengangkatnya ke dalam suatu penelitian yang berjudul "Pengaruh Penggunaan Media Sosial Whatsapp dan BookletTerhadap Pengetahuan Tentang Rokok dan Sikap Siswa di SMA Negeri 13 Medan".

\section{METODE PENELITIAN}

Jenis penelitian yang digunakan adalah eksperimen semu (Quasi experiment), dengan rancangan non-equivalent control group design di SMA Negeri 13 Medan dengan menggunakan data primer dan skunder. Populasi dalam penelitian ini adalah seluruh siswaSMAN 13 Medankelas 11 tahun ajaran 2018/2019 sebanyak 128 orang laki-laki. Penelitian ini menggunakan teknik purporsive sampling, yaitu teknikpenentuan sampel dengan pertimbangan tertentu (Arikunto, 2010).Penarikan sampelpurporsive dengan mempertimbangkan jenis penelitian yang digunakan dimana dalam penelitian ini membutuhkan kelas kontrol dan kelas eksperimen.

Kelas yang dijadikan sampel dalam penelitian ini adalah kelas kelas 11 yang memenuhi kriteria yaitu:

a. Siswa mempunyai media sosial WA.

b. Siswa aktif menggunakan media sosial WA.

Berdasarkan hal tersebut maka sampel penelitian ini sebanyak 21 siswa laki-laki untuk kelompok eksperimen (media sosial WA) dan 21 siswa laki-laki untuk kelompok kontrol (booklet).

\section{HASIL DAN PEMBAHASAN}

Hasil Analisis penelitian ini disajikan dalam analisis Univariat dan analisis Bivariat

\section{Analisis Univariat}

Tabel 1. Distribusi Frekuensi Pengetahuan Tentang Rokok Pada Siswa di SMA Negeri 13

$$
\text { Medan }
$$

\begin{tabular}{|c|c|c|c|c|c|c|c|c|}
\hline \multirow{3}{*}{$\begin{array}{c}\text { Variabel } \\
\text { Pengetahuan }\end{array}$} & \multicolumn{4}{|c|}{ Media Sosial Whatsapp } & \multicolumn{4}{|c|}{ Media Booklet } \\
\hline & \multicolumn{2}{|c|}{ Pre-Test } & \multicolumn{2}{|c|}{ Post Test } & \multicolumn{2}{|c|}{ Pre-Test } & \multicolumn{2}{|c|}{ Post Test } \\
\hline & f & $\%$ & f & $\%$ & f & $\%$ & f & $\%$ \\
\hline Baik & 11 & 52,4 & 14 & 66,7 & 10 & 47,6 & 19 & 90,5 \\
\hline Kurang & 10 & 47,6 & 7 & 33,3 & 11 & 52,4 & 2 & 9,5 \\
\hline Total & 21 & 100 & 21 & 100 & 21 & 100 & 21 & 100 \\
\hline
\end{tabular}

Dari tabel 1 di atas menunjukkan hasil pengetahuan siswa pada kelompok media sosial whatsapp sebelum diberi perlakuan (Pre-Test) dengan kategori baik sebanyak 11 responden $(52,4 \%)$ dan kategori kurang sebanyak 10 responden (47,6\%), dan setelah diberi perlakuan(Post Test) diketahui pengetahuan dengan kategori baik sebanyak14responden $(66,7 \%)$ dan kategori kurang sebanyak 7responden $(33,3 \%)$. Selanjutnya hasil pengetahuan siswa pada kelompok media booklet sebelum diberi perlakuan (Pre-Test) dengan kategori baik sebanyak 10 responden $(47,6 \%)$ dan kategori kurang sebanyak 11 responden (52,4\%), dan setelah diberi perlakuan(Post Test) diketahui pengetahuan dengan kategori baik sebanyak19 responden $(90,5 \%)$ dan kategori kurang sebanyak 2 responden $(9,5 \%)$. 
Tabel 2. Distribusi Frekuensi Sikap Tentang Rokok Pada Siswa di SMA Negeri 13 Medan

\begin{tabular}{ccccccccc}
\hline \multirow{2}{*}{ Variabel } & \multicolumn{3}{c}{ Media Sosial Whatsapp } & \multicolumn{3}{c}{ Media Booklet } \\
\cline { 2 - 9 } Sikap & \multicolumn{1}{c}{ Pre-Test } & \multicolumn{1}{c}{ Post Test } & Pre-Test & Post Test \\
\cline { 2 - 9 } & f & \% & f & \% & f & \% & f & \% \\
\hline Positif & 8 & 38,1 & 14 & 66,7 & 7 & 33,3 & 18 & 85,7 \\
Negatif & 13 & 69,1 & 7 & 33,3 & 14 & 66,7 & 3 & 14,3 \\
\hline Total & 21 & 100 & 21 & 100 & 21 & 100 & 21 & 100 \\
\hline
\end{tabular}

Dari tabel 2. di atas menunjukkan hasil sikap siswa pada kelompok media sosial whatsapp sebelum diberi perlakuan (Pre-Test) dengan kategori positif sebanyak 8 responden $(38,1 \%)$ dan kategori negatif sebanyak 13 responden $(69,1 \%)$, dan setelah diberi perlakuan(Post Test) diketahui sikap siswa dengan kategori baik sebanyak14 responden $(66,7 \%)$ dan kategori kurang sebanyak 7 responden $(33,3 \%)$. Selanjutnya hasil sikap siswa pada kelompok media bookletsebelum diberi perlakuan (Pre-Test) dengan kategori positif sebanyak 7 responden $(33,3 \%)$ dan kategori negatif sebanyak 14 responden $(66,7 \%)$, dan setelah diberi perlakuan(Post Test) diketahui sikap siswa dengan kategori positif sebanyak18 responden dan kategori negatif sebanyak 3 responden $(14,3 \%)$.

\section{Analisis Bivariat}

Tabel 3. Analisa Pengaruh Media WhatsappTerhadap PengetahuanTentang RokokPada Siswa di SMA Negeri 13 Medan

\begin{tabular}{lcccc}
\hline Pengetahuan & Mean & thitung & tabel & $\begin{array}{c}\text { Asymp. Sig(2- } \\
\text { tailed })\end{array}$ \\
\hline Pre-Test & 5,95 & 5,541 & 2,0796 & 0,022 \\
Post-Test & 6,95 & & & \\
\hline
\end{tabular}

Dari tabel 3 di atas menunjukkan bahwa nilai rata-rata pengetahuan siswa sebelum diberi perlakuan media whatsappyaitu 5,95 dan setelah diberi perlakuan dengan media whatsapp diperoleh 6,95 yang artinya ada peningkatan pengetahuan siswa setelah diberi perlakuan dengan media whatsapp. Selanjutnya diperoleh nilai $t_{\text {hitung }}=5,541$ lebih besar dari nilai $t_{\text {tabel }}=2,0796$ dan nilai $\mathrm{p}=0,022$ yang artinya media whatsappberpengaruh terhadap pengetahuan tentang rokok pada siswadi SMA Negeri 13 Medan.

Tabel 4. Analisa Pengaruh Media Whatsapp Terhadap Sikap Tentang RokokPada Siswa di SMA Negeri 13 Medan

\begin{tabular}{ccccc}
\hline Sikap & Mean & thitung & tabel & $\begin{array}{c}\text { Asymp. Sig(2- } \\
\text { tailed) }\end{array}$ \\
\hline Pre-Test & 30,67 & 4,431 & 2,0796 & 0,000 \\
Post-Test & 35,24 & & & \\
\hline
\end{tabular}


Dari tabel 4 di atas menunjukkan bahwa nilai rata-rata sikap siswa sebelum diberi perlakuan dengan media whatsapp yaitu 30,67 dan setelah diberi perlakuan media whatsapp diperoleh 35,24 yang artinya ada peningkatan pada sikap tentang rokok setelah diberi perlakuan dengan media whatsapp pada siswa di SMA Negeri 13 Medan. Selanjutnya dari hasil uji statistik diperoleh nilainilai $t_{\text {hitung }}=4,431$ lebih besar dari nilai $t_{\text {tabel }}=2,0796$ dan nilai $p=0,000$ yang artinya media whatsapp berpengaruh terhadap sikap tentang rokok pada siswa di SMA Negeri 13 Medan.

Tabel 5. Analisa Pengaruh Media Booklet Terhadap PengetahuanTentang Rokok Pada Siswa di SMA Negeri 13 Medan

\begin{tabular}{lcccc}
\hline Pengetahuan & Mean & thitung & t tabel & $\begin{array}{c}\text { Asymp. Sig(2- } \\
\text { tailed })\end{array}$ \\
\hline Pre-Test & 4,95 & 7,129 & 2,0796 & 0,000 \\
Post-Test & 8,38 & & & \\
\hline
\end{tabular}

Dari tabel 5 di atas menunjukkan bahwa nilai rata-rata pengetahuan siswa sebelum diberi perlakuan dengan media booklet yaitu 4,95 dan setelah diberi perlakuan dengan media booklet diperoleh 8,35 yang artinya ada peningkatan pengetahuan siswa tentang rokok etelah diberi perlakuan dengan media booklet. Selanjutnya dari hasil uji statistik diperoleh nilai $t_{\text {hitung }}=7,129$ lebih besar dari nilai $t_{\text {tabel }}=2,0796$ dan nilai $\mathrm{p}=0,000$ yang artinya media booklet berpengaruh terhadap pengetahuan tentang rokok pada siswa di SMA Negeri 13 Medan.

Tabel 6. Analisa Pengaruh Media Booklet Terhadap Sikap Tentang Rokok Pada Siswa di SMA Negeri 13 Medan

\begin{tabular}{ccccc}
\hline Variabel & Mean & thitung & tabel & $\begin{array}{c}\text { Asymp. Sig(2- } \\
\text { tailed })\end{array}$ \\
\hline Pre-Test & 29,81 & 7,158 & 2,0796 & 0,000 \\
Post-Test & 40,00 & & & \\
\hline
\end{tabular}

Dari tabel 6 di atas menunjukkan bahwa nilai rata-rata sikap siswa sebelum diberi perlakuan dengan media booklet yaitu 29,81 dan setelah diberi perlakuan media booklet diperoleh 40,00 yang artinya ada peningkatan pada sikap siswa tentang setelah diberi perlakuan dengan media booklet . Selanjutnya diperoleh nilai thitung $=7,158$ lebih besar dari nilai $t_{\text {tabel }}=2,0796$ dan nilai $\mathrm{p}=$ 0,000 yang artinya media booklet berpengaruh terhadap sikap tentang rokok pada siswa di SMA Negeri 13 Medan.

Berdasarkan hasil uji statistik antara media sosial whatsapp terhadap pengetahuan tentang rokok diperoleh nilai $\mathrm{p}=0,022$ yang menunjukkan media social whatsapp berpengaruh terhadap pengetahuan tentang rokok pada siswa di SMA Negeri 13 Medan. Pengaruh tersebut dapat diketahui melaui nilai rata-rata pengetahuan siswa sebelum diberi perlakuan media whatsapp diperoleh 5,95 dan setelah diberi perlakuan dengan media whatsapp menjadi 6,95 yang artinya pengetahuan siswa meningkat setelah diberi perlakuan dengan media whatsapp. Hasil ini sejalan dengan pendapat Rusni dan Lubis (2017) yang mengemukakan bahwa whatsapp memiliki kelebihan yaitu dapat mengirimkan tulisan, gambar, video, audio dan pesanan suara dengan mudah tanpa cost yang tinggi. Nasrullah (2017) mendefinisikan media sosial sebagaimedia online yang mendukung interaksi sosial. Media sosial adalah mengenai menjadi manusia biasa. 
Manusia biasa yang saling membagi ide, bekerjasama dan berkolaborasi untuk menciptakan kreasi, berpikir, berdebat, menemukan orang yang bisa menjadi teman baik, menemukan pasangan dan membangun sebuah komunitas. Intinya, menggunakan media sosial menjadikan kita sebagai diri sendiri. Salah satu media sosial yang sering digunakan adalah whatsapp.

Berdasarkan hasil hasil uji statistik antara media sosial whatsapp terhadap sikap tentang rokok diperoleh nilai $\mathrm{p}=0,000$ yang menunjukkanmedia whatsapp berpengaruh terhadap sikap tentang rokok pada siswa di SMA Negeri 13 Medan. Pengaruh tersebut dapat diketahui melaui nilai ratarata sikap siswa sebelum diberi perlakuan media whatsapp diperoleh 30,67 dan setelah diberi perlakuan dengan media whatsapp menjadi 35,24yang artinya sikap siswa meningkat setelah diberi perlakuan dengan media whatsapp. Haenlein (2010) mengungkapkan bahwa media sosial didefinisikan sebagai media online dengan para penggunanya bisa dengan mudah berpartisipasi, berbagi dan menciptakan isi. Demikian pula di dalam penelitian ini, media sosial whatsapp digunakan untuk berpartisipasi dan berbagi pengetahuan tentang rokok. Melalui media sosial whatsapp sebagai alat komunikasi, para siswa dapat berbagi informasi tentang rokok untuk menambah pengetahuan mereka dan melalui pengetahuan yang diperoleh tersebut diharapkan para siswa dapat mengambil sikap positif tentang rokok yang diantaranya adalah tidak menggunakan rokok ataupun mencoba-coba untuk merokok, karena bila seseorang merokok dapat membuat perokok tersebut ketagihan.

Berdasarkan hasil uji statistik diperoleh nilai $\mathrm{p}=0,000$ yang menunjukkanmedia booklet berpengaruh terhadap pengetahuan tentang rokok pada siswa di SMA Negeri 13 Medan. Pengaruh tersebut dapat diketahui melalui nilai rata-rata pengetahuan siswa sebelum diberi perlakuan media booklet iperoleh 4,95 dan setelah diberi perlakuan dengan media booklet menjadi 8,38 yang artinya pengetahuan siswa meningkat setelah diberi perlakuan dengan media booklet. Pengetahuan tentang rokok melalui media booklet yang paling menonjol tersebut adalah bahwa seseorang merokok dapat dilatar belakangi khawatir tidak diterima teman (Sadikin dan Louisa, 2008) serta agar seseorang tidak merokok, maka hal yang harus dilakukan adalahjangan coba-coba (Cahyo, dkk, 2012). Dari hasil penelitian ini menunjukkan bahwa media booklet memberikan pengaruh terhadap pengetahuan tentang rokok dan sikap siswa. Hal ini menurut Ewles (1994)(dalam Roza, 2012) disebabkan media booklet memiliki kelebihan yaitu: a) Dapat digunakan sebagai media atau alat belajar mandiri, b) Dapat dipelajari isinya dengan mudah, c) Dapat disajikan informasi secara spesifik, d) Mudah dibuat, diperbanyak dan diperbaiki serta mudah disesuaikan, e) Mengurangi kebutuhan mencatat, f) Dapat dibuat secara sederhana dengan biaya relatif murah dan, g) Tahan lama. Hasil penelitian ini sesuai dengan penelitian Puspitaningrum, dkk (2017) yang menunjukkan bahwa ada perbedaan pengetahuan dan sikap remaja putri sebelum dan sesudah diberi perlakuan media booklet. Faktor yang mempengaruhi peningkatan pengetahuan remaja putri dipengaruhi oleh jarak antara waktu intervensi dengan posttestkarena berhubungan dengan ingatan dalam menyimpan informasi (retensi).

Berdasarkan hasil uji statistik diperoleh nilai $\mathrm{p}=0,000$ yang menunjuk kanmedia booklet berpengaruh terhadap sikap tentang rokok pada siswa di SMA Negeri 13 Medan. Pengaruh tersebut dapat diketahui melalui nilai rata-rata siswa siswa sebelum diberi perlakuan media booklet diperoleh 29,81 dan setelah diberi perlakuan media booklet diperoleh 40,00 yang artinya ada peningkatan pada sikap siswa tentang setelah diberi perlakuan dengan media booklet. Hasil penelitian ini sesuai dengan pendapat Haenlein (2010) yang mengungkapkan bahwa media sosial didefinisikan sebagai media online dengan para penggunanya bisa dengan mudah berpartisipasi, berbagi dan menciptakan isi. Demikian pula di dalam penelitian ini, media bookletdigunakan 
untuk berpartisipasi dan berbagi pengetahuan tentang rokok. Melalui media bookletsebagai alat informasi, para siswa dapat berbagi informasi tentang rokok untuk menambah pengetahuan mereka dan melalui pengetahuan yang diperoleh tersebut diharapkan para siswa dapat mengambil sikap positif tentang rokok yang diantaranya adalah tidak menggunakan rokok ataupun mencoba-coba untuk merokok, karena bila seseorang merokok dapat membuat perokok tersebut ketagihan. Dari uraian di atas dapat disimpulkan bahwa media sosial whatsapp berpengaruh terhadap sikap siswa. Media sosial whatsapp dapat memberikan dampak yang positif bila digunakan untuk media penyuluan atau pembelajaran.

Hasil penelitian ini sesuai dengan penelitian Puspitaningrum, dkk (2017) yang menunjukkan bahwa ada perbedaan sikap remaja putri sebelum dan sesudah diberi perlakuan media booklet.

Demikian pula penelitian Dharmastuti (2017) menunjukkan bahwa ada perbedaan sikap tentang bahaya merokok antara pretest dan posttest. Peningkatan nilai rata-rata sikap antara sebelum dan sesudah diberikan perlakuan dengan media booklet yakni 40,43 menjadi 52,99. Terdapat peningkatan nilai rata-rata sikap antara sebelum dan sesudah diberikan perlakuan dengan mediabooklet sebesar 12,57. Hasil uji statistikkelompok media booklet didapatkan nilai $\mathrm{p}=0,0001$, sehingga dapat disimpulkan bahwa ada perbedaan sikap siswa tentang bahaya merokok antara sebelum dan sesudah diberi pendidikan kesehatan dengan media booklet.

\section{KESIMPULAN DAN SARAN}

Berdasarkan hasil penelitian di SMA Negeri 13 Medan menunjukan Penggunaan media social whatsapp berpengaruh terhadap pengetahuan tentang rokok dan sikap siswa dan Penggunaan media booklet berpengaruh terhadap pengetahuan tentang rokok dan sikap siswa. Adapun saran bagi kepala sekolah Diharapkan pihak sekolah dapat menggunakan media booklet dan media WA untuk memberikan pemahaman tentang bahaya merokok bagi siswa yang dapat dilakukan pada kegiatan ekstrakurikuler dan Bagi Dinas Kesehatan diharapkan Dinas Kesehatan untuk memberi pemahaman kepada para remaja melalui penyuluhan ataupun memberikan informasi melalui media booklet atau media whatsapp agar para remaja tidak terjerumus dengan perilaku merokok.

\section{Ucapan Terimakasih}

Penulis mengucapkan terimakasih kepada kepala sekolah SMA Negeri 13 Medan yang telah memberikan dukungan terhadap penelitian ini.

\section{REFERENSI}

Aini, F. (2010). Pengaruh Pendidikan Kesehatan Resproduksi Remaja Melalui Media Booklet terhadap Perubahan Pengetahuan dan Sikap Santri tentang Kesehatan Reproduksi di Pesantren Darul Hikmah dan Ta'dib Al Syakirin di Kota Medan Tahun 2010. Medan: Fakultas Kesehatan Masyarakat Universitas Sumatra Utara

Cahyo, K.,Wigati, P.A., Shaluhiyah, Z. (2012). Rokok, Pola Pemasaran dan Perilaku Merokok Siswa SMA/Sederajat di Kota Semarang. Media Kesehatan Masyarakat Indonesia.Vol. 11 / No. 1, April 2012.

Gazali, G. (2014). Pengaruh pemberian Promosi Kesehatan Melalui Media Sosial Facebook Terhadap Pengetahuan Tentang Bahaya Merokok pada Mahasiswa Semester 8 di Universitas Muhammadiyah Yogyakarta.

Haenlein, M. (2010). Users of the world, unite! The challenges and opportunities of Social Media. Business Horizons. 
Jumiatmoko. (2016). WhatsApp Messenger dalam Tinjauan Manfaat dan Adab. Jurnal Wahana, 51-66.

Kemenkes RI. (2016). Perilaku Merokok Masyarakat Indonesia. Jakarta: Pusat Data dan Informasi Kementrian Kesehatan Republik Indonesia

Notoatmodjo, S. (2012). Promosi kesehatan dan Perilaku Kesehatan. Jakarta: Rineka Cipta

Nasrullah, R. (2017). Media Sosial : Perspektif Komunikasi, Budaya, dan Sosioteknologi. Bandung : Remaja Rosdakarya.

Puspitaningrum, W., Farid A., Atik M., Djoko, N. (2017). Pengaruh Media Booklet Terhadap Pengetahuan dan Sikap Remaja Putri Terkait Kebersihan Dalam Menstruasi di Pondok Pesantren Al-Ishlah Demak Triwulan II Tahun 2017. Jurnal Kesehatan MasyarakatVolume 5, Nomor 4, Oktober 2017, Universitas Diponegoro

Riskesdas, 2010, 2013, 2018. Badan Penelitian dan Pengembangan Kesehatan Departemen Kesehatan Republik Indonesia. Laporan hasil riset kesehatan data nasional (RISKESDAS). Jakarta: Departemen Kesehatan Republik Indonesia.

Roza, F., (2012). Media Gizi Booklet. Padang: Poltekkes Kemenkes RI Padang.

Rusni, A. \& Lubis, Elysa E .(2017). Penggunaan Media Online Whatsapp Dalam Aktivitas Komunitas One Day One Juz (Odoj) Dalam Meningkatkan Minat Tilawah Odojer Di Kota Pekanbaru. Jurnal Online Mahasiswa (JOM) Vol. 2, No.1 April 2017.

Sirait, A.M. (2002). Perilaku Merokok di Indonesia. Buletin Penelitian. Kesehatan 30

Sabiq, J. (2019). 10 Kelebihan dan Keunggulan serta Alasan Menggunakan Whatsapp. Diakses dari: https://www.duosia.id/android/kelebihan-dan-keunggulan-serta-alasanmenggunakan-whatsapp/

Sadikin, Z.D dan Louisa, M. (2008). Program Berhenti Merokok. Jakarta : Departemen Farmakologi dan Terapeutik, Fakultas Kedokteran Universitas Indonesia.

WHO, (2016). Indonesia's tobacco profile. WHO report on the global tobacco epidemic. The MPOWER package. Geneva: World Health Organization. 
